\title{
Effect of Fertilizer Application on Growth and Yield of Manihot esculenta Crantz.
}

\author{
K. Sungthongwises ${ }^{1}$, Anucha Laoken ${ }^{2} \&$ Anan Polthanee ${ }^{3}$ \\ ${ }^{1}$ Agronomy section, Faculty of Agriculture, Khon Kaen University, Khon Kaen, Thailand \\ ${ }^{2}$ Mahasarakham Research and Development Agriculture Centre, Mahasarakham, Thailand \\ ${ }^{3}$ Agricultural Extension and Agricultural Systems, Faculty of Agriculture, Khon Kaen University, Khon Kaen, \\ Thailand \\ Correspondence: Kiriya Sungthongwises, Agronomy section, Faculty of Agriculture, Khon Kaen University, \\ Khon Kaen, Thailand. Tel: 00-66-090-324-1635. E-mail: skiriy@kku.ac.th
}

Received: May 15, 2020

doi:10.5539/jas.v12n8p152

Accepted: June 15, $2020 \quad$ Online Published: July 15, 2020

URL: https://doi.org/10.5539/jas.v12n8p152

The research is financed by General Research Grant 2018 to Khon Kaen University.

\begin{abstract}
To investigate the effect of chemical and organic fertilizer management on growth, yield and nutrient uptake of two cassava cultivars under rainfed conditions, the study was laid out in factorial in randomised complete block design with four replications. The six treatments were TR1) Kasetsart 50 with $312.50 \mathrm{~kg} \mathrm{ha}^{-1}$ of 15-15-15, TR2) CMR 33-38-48 with $312.50 \mathrm{~kg} \mathrm{ha}^{-1}$ of $15-15-15$, TR3) Kasetsart 50 with $312.50 \mathrm{~kg} \mathrm{ha}^{-1}$ of 15-7-18, TR4) CMR 33-38-48 with $312.50 \mathrm{~kg} \mathrm{ha}^{-1}$ of 15-7-18, TR5) Kasetsart 50 with $6,250 \mathrm{~kg} \mathrm{ha}^{-1}$ of organic fertilizer and TR6) CMR 33-38-48 with $6,250 \mathrm{~kg} \mathrm{ha}^{-1}$ of organic fertilizer. The results illustrated that Kasetsart 50 responded to chemical fertilizer management especially, $312.50 \mathrm{~kg} \mathrm{ha}^{-1}$ of $15-7-18$ formula and $6,250 \mathrm{~kg} \mathrm{ha}^{-1}$ of organic fertilizer at 1 and 4 months after planting respectively, better than CMR 33-38-48 in terms of storage root fresh and dry weights, percentage of total starch and amylose content. CMR 33-38-48 responds to chemical fertilizer management and organic fertilizers in terms of stem and leaf growth.
\end{abstract}

Keywords: amylose, cassava, cultivars, fertilizer, macronutrients content

\section{Introduction}

Yield of cassava can be increased by many methods, such as choosing the right cassava varieties that suitable for the soil and planting area together with the fertilizer management techniques. Farmers should use the cassava varieties that are well adapted to the environment, providing high fresh storage roots and starch content. In addition, good cassava varieties must also have a special characteristics for example, good germination, high survival, fast-growing, well-covered weeds, resistance to insect and diseases, easy to harvest and is the species that market needs. Most of the planting areas in the northeastern region are low cassava production efficiency (Office of Agricultural Economics, 2015). As a result of soil degradation in chemical, biological and lack of proper soil management (Howeler, 1995; Wargiono et al., 1995). There are many varieties of good cassava in Thailand, such as Kasetsart 50, Rayong 5, Rayong 7, Rayong 72, Rayong 90 and new variety (CMR 33-38-48) with a short life suggested to grow in sandy loam and paddy field after rice harvesting. For the germination speed, the fastest germinating varieties are Rayong 7 and Kasetsart 50 which is able to germinate $88-96 \%$ within 1 week after planting (Office of Agricultural Economics, 2004). More than $50 \%$ of farmers in Thailand, prefer to use chemical fertilizer 15-15-15 formula but the department of agriculture recommends the 15-7-18 formula because the nutrients are close to the needs of cassava by the low amount of phosphorus. The chicken manure is an organic fertilizer with high potential to increase the storage roots number and root weight per plant. According to chicken manure fertilizer high in organic matter, $\mathrm{N}, \mathrm{P}, \mathrm{K}, \mathrm{Ca}$ and $\mathrm{Mg}$ which is the recommended rate between 3,125-6,250 kg ha-1 (Chutangka, 2008). Thongsri et al. (2007) studied the influence of NPK fertilizer, organic fertiliser and above ground cassava ploughing on soil fertility. The results showed that non fertilizered cassava causes both growth and yield to be greatly reduced. This included the status of soil fertility and planting date in particular, in the sandy loam-like Yasothon soil series. To maintain soil fertility and cassava 
production, proper fertilizer management is necessary. The moderate use of nitrogen $(\mathrm{N})$, phosphorus $(\mathrm{P})$ and potassium (K) significantly increase cassava production. The Department of Agriculture has suggested the use of short-duration variety, namely CMR 33-38-48 with fertilizer application according to soil analysis 1 month after planting compared to the farmers' practice of using cassava variety Kasetsart 50 with chemical fertilizer $15-15-15$ formula at a rate of $312.50 \mathrm{~kg} \mathrm{ha}^{-1}$ before planting. The study found that planting cassava variety CMR 33-38-48 with fertilizer application according to soil analysis, the storage roots fresh weight increased by $37.7 \%$ and $79.0 \%$ when compared to the methods that farmers practiced in 2013 and 2014, respectively, and gave a return on investment or marginal rate of return (MRR) of $646 \%$ and $830 \%$ in the years 2013 and 2014, respectively (Wanasai et al., 2014). Phankamonsil and Wiriyaphanit (2017) studied different nutrient management on soil properties and showed significant differences in the plant height and storage roots fresh weight of cassava. Chemical fertiliser application according to soil analysis and cassava requirements according to the recommendation of the Department of Land Development (2004) resulted in average stem heights at 3, 6 and 9 months of $84.9,171.3$ and $179.7 \mathrm{~cm}$, respectively. Soil planting to cassava in the northeastern region belong to the Paleustults group, namely the Warin, Korat, Satuk and Yasothon soil series (Anusontpornperm et al., 2005). Yasothorn soil in the Northeast Thailand is low fertility and limited by a strong deficiency in phosphorus and sulfur. In addition, most farmers grow cassava continuously and added less fertilizer than plants removed from the soil. Therefore, this study aims to compare the management methods of chemical fertilizer and organic fertilizers that affect growth, yield and nutrient uptake of cassava varieties Kasetsart 50 and CMR 33-38-48 in Yasothon soil series. The results of this study will be beneficial to the production of cassava safely and maintaining long-term soil fertility.

\section{Method}

\subsection{Planting Material Preparation}

Two cassava varieties stake (Kasetsart 50 and CMR 33-38-48) were prepared at the Mahasarakham Research and Development Agriculture Centre, Mahasarakham province, Thailand from 2017 to 2018. It is an area of sandy loam with pH 5.36, total $\mathrm{N} 0.018 \%$, available $\mathrm{P} 9.88 \mathrm{mg} \mathrm{kg}^{-1}$, exchangeable $\mathrm{K} 26.70 \mathrm{mg} \mathrm{kg}^{-1}$ and organic matter $0.35 \%$. A total rainfall of $1,216 \mathrm{~mm}$ occurred during the crop growth period of 10 months. The maximum and minimum temperatures were recorded as 33 and $23{ }^{\circ} \mathrm{C}$, respectively (Sungthongwises et al., 2016). Planting was done on ridges spaced $1.80 \mathrm{~m}$, cassava stake cuttings $25 \mathrm{~cm}$ long, were hand planted on the crests of ridges on June 2017 to April 2018. Fertilizer (15-15-15 and 15-7-18 kg NPK) application was applied at the rates of $312.50 \mathrm{~kg} \mathrm{ha}^{-1}$ during land preparation and 4 months after planting.

\subsection{Site Description and Experimental Design}

Experiments were carried out in the experimental field at Faculty of Agriculture, Khon Kaen University, located in the Northeastern Thailand from July 2018 to July 2019. It is an area of sandy namely the Yasothon soil where the soils are low fertility and characterized by high percentages of sands and a low thickness of humus. The soil pH 5.37-5.84, total nitrogen, available phosphorus, exchangeable calcium, available zinc, electrical conductivity and cation exchange capacity did not have significant differences. The amounts of exchangeable potassium and magnesium, sulphur extractable and the amount of organic matter were significant difference from the soil surface to a depth of $30 \mathrm{~cm}$ (Table 1). Annual mean precipitation was $1,198 \mathrm{~mm}$ during the period of cassava growth with the average maximum and minimum temperatures about 34.52 and $24.98{ }^{\circ} \mathrm{C}$, respectively. The trial was established as a factorial in randomised complete block design with four replications. The first factors were comprised of two cassava varieties, Kasetsart 50 and CMR 33-38-48. The second factors consisted of three fertilizer management types: 1) $312.50 \mathrm{~kg} \mathrm{ha}^{-1}$ of 15-15-15 at 1 and 4 months after planting, 2) $312.50 \mathrm{~kg} \mathrm{ha}^{-1}$ of 15-7-18 at 1 and 4 months after planting and 3) 6,250 $\mathrm{kg} \mathrm{ha}^{-1}$ of organic fertilizer at 1 and 4 months after planting. Fertilizer application were devided in 50:50 at 1 and 4 months after planting. Stakes were soaked with imidacloprid at a concentration of $3 \mathrm{~g}$ per $20 \mathrm{~L}$ of water for $10 \mathrm{~min}$ for all treatments. The $25 \mathrm{~cm}$ stakes were planted vertically with $1 \mathrm{~m} \times 0.8 \mathrm{~m}$ spacing in sub-trial plots, size $4 \times 8 \mathrm{~m}$. Weed control was carried out by using pre-emergence herbicide S-metolachlor at a rate of $175 \mathrm{ml}$ per $80 \mathrm{l}$ of water and flumioxazin at a concentration of $10 \mathrm{~g}$ per $80 \mathrm{l}$ of water and hand weeding at 1 month after planting (Sungthongwises et al., 2016). The germination percentage was measured at 30 days after planting. Cassava growth and development were measured for 4,8 and 12 months after planting. 
Table 1. Soil chemical properties at $0-30 \mathrm{~cm}$ before growing cassava

\begin{tabular}{|c|c|c|c|c|c|c|}
\hline \multirow{2}{*}{ Soil chemical properties } & \multicolumn{6}{|c|}{ Treatments } \\
\hline & $\operatorname{Tr} 1$ & $\operatorname{Tr} 2$ & $\operatorname{Tr} 3$ & $\operatorname{Tr} 4$ & $\operatorname{Tr} 5$ & Tr6 \\
\hline $\mathrm{pH}\left(1: 5 \mathrm{H}_{2} \mathrm{O}\right)$ & 5.81 & 5.47 & 5.61 & 5.72 & 5.84 & 5.37 \\
\hline Total N (\%) & 0.03 & 0.03 & 0.03 & 0.03 & 0.03 & 0.03 \\
\hline Available P (ppm) & 29.22 & 37.82 & 29.85 & 38.08 & 30.63 & 37.35 \\
\hline Exchangeable K (ppm)* & $69.25 \mathrm{ab}$ & $82.10 \mathrm{a}$ & $67.22 b$ & $74.86 \mathrm{ab}$ & $73.64 \mathrm{ab}$ & $81.03 \mathrm{ab}$ \\
\hline Exchangeable $\mathrm{Ca}$ (ppm) & 219.09 & 262.19 & 299.72 & 256.03 & 304.26 & 335.39 \\
\hline Exchangeable $\mathrm{Mg}(\mathrm{ppm})^{*}$ & $138.68 \mathrm{a}$ & $122.23 \mathrm{ab}$ & $137.91 \mathrm{a}$ & $115.25 b$ & $130.68 \mathrm{ab}$ & $113.30 \mathrm{~b}$ \\
\hline Available Zn (ppm) & 0.56 & 0.60 & 0.47 & 0.53 & 0.48 & 0.47 \\
\hline Extractable $\mathrm{SO}_{4}{ }^{2-}(\mathrm{ppm})^{*}$ & $11.71 \mathrm{ab}$ & $11.08 \mathrm{ab}$ & $12.85 \mathrm{a}$ & $10.78 \mathrm{ab}$ & $10.98 \mathrm{ab}$ & $10.02 b$ \\
\hline $\mathrm{OM}(\%)^{*}$ & $0.40 \mathrm{ab}$ & $0.44 \mathrm{ab}$ & $0.37 b$ & $0.42 \mathrm{ab}$ & $0.49 \mathrm{a}$ & $0.46 \mathrm{ab}$ \\
\hline $\mathrm{EC}(\mathrm{dS} / \mathrm{cm})$ & 11.68 & 14.52 & 13.89 & 16.00 & 18.10 & 20.58 \\
\hline $\mathrm{CEC}(\mathrm{me} / 100 \mathrm{~g})$ & 3.67 & 3.34 & 3.34 & 3.45 & 3.79 & 3.53 \\
\hline
\end{tabular}

Note. TR1 $=$ Kasetsart $50+312.50 \mathrm{~kg} \mathrm{ha}^{-1}$ of 15-15-15; TR2 = CMR 33-38-48 +312.50 $\mathrm{kg} \mathrm{ha}^{-1}$ of 15-15-15; TR3 $=$ Kasetsart $50+312.50 \mathrm{~kg} \mathrm{ha}^{-1}$ of 15-7-18; TR4 = CMR 33-38-48 $+312.50 \mathrm{~kg} \mathrm{ha}^{-1}$ of 15-7-18; TR5 = Kasetsart 50+6,250 $\mathrm{kg} \mathrm{ha}^{-1}$ of organic fertilizer; TR6 $=$ CMR 33-38-48 $+6,250 \mathrm{~kg} \mathrm{ha}^{-1}$ of organic fertilizer.

Different letters indicate a significant difference at $\mathrm{p} \leq 0.05^{*}$.

\subsection{Macronutrient Content of Stem Cuttings}

Kasetsart 50 and CMR 33-38-48 stakes were cut into $25 \mathrm{~cm}$ pieces for macronutrients [nitrogen $(\mathrm{N})$, phosphorus (P) and potassium $(\mathrm{K})$ ] content analysis. $\mathrm{N}$ biomass content was measured by the micro-Kjeldahl method with indophenol blue, $\mathrm{P}$ content by wet oxidation and spectrophotometry and $\mathrm{K}$ content by wet oxidation and flame photometry (Sungthongwises et al., 2016) at Northeast Agriculture Research and Development Center in the Faculty of Agriculture, Khon Kaen University.

\subsection{Total Starch and Amylose Content of Cassava Storage Roots}

Total starch was measured by measurement of specific gravity in the storage root with starch percentage scales in cassava roots. Amylose content was measured by cassava roots were ground into a flourmill. Then, $0.10 \mathrm{~g}$ of flour were weighed, put in a $100 \mathrm{ml}$ volume glass bottle that is completely dry. First, $1 \mathrm{ml}$ of $95 \%$ ethyl alcohol was added and shaken gently to spread the powder evenly. Then, $9 \mathrm{ml}$ of sodium hydroxide solution was added. The magnetic rod was put into the glass bottle, and the sample was stirred with a magnetic stirrer for 10 minutes to make flour. Then, the magnet was removed from the glass bottle and the volume was adjusted with distilled water to $100 \mathrm{ml}$, the cork was closed, and shaken well. A new $100 \mathrm{ml}$ capacity glass bottle was prepared. Then, approximately $70 \mathrm{ml}$ of distilled water were added, and $2 \mathrm{ml}$ of glacial acetic acid solution and $2 \mathrm{ml}$ of iodine solution were added. Afterwards, $5 \mathrm{ml}$ of starch were added to a prepared glass bottle. The volume was adjusted with distilled water to $100 \mathrm{ml}$. The cork was closed and shaken well. Then it was set aside for 10 minutes. The colour intensity of the solution measured with a spectrophotometer by reading as absorbance at $620 \mathrm{~nm}$ wavelength after adjusting the machine with blank to absorbance equal to 0 (zero). To make the blank, $2 \mathrm{ml}$ of acetic acid solution and $2 \mathrm{ml}$ iodine solution were added. The volume was adjusted with distilled water to $100 \mathrm{ml}$. The absorbance value was compared to the percent amylose by comparing the standard curve provided (Ministry of Commerce, 2016).

\subsection{Statistical Analysis}

The data were then subjected to analysis of variance according to the experimental design by Statistix version 8.0 software. Means were calculated by sub-plot. When the effects were significant, means were compared using the least significant differences (L.S.D.) at a significance level of 0.05 among treatments.

\section{Results and Discussion}

\subsection{Macronutrients Content in Cassava Stem Pieces Before Planting}

Cassava varieties Kasetsart 50 had higher stake moisture content than CMR 33-38-48 while nitrogen, phosphorus and potassium contents were not significantly different (Table 2) before planting. Boonma et al. (n.d.) reported that cassava strains were significantly different in the percentage of stake moisture content, germination and survival. The cultivar MKUC 34-114-106 had the percentages of germination and survival 
$96.7 \%$ and $95.4 \%$, respectively. When kept outdoors and covering the base compared to under shade, the stake moisture contents of cassava were $66.1 \%$ and $62.8 \%$ respectively. When keeping the storage time longer, stake moisture content, germination, the survival percentage and also the production of fresh and dry storage roots tended to decrease.

Table 2. Macronutrient content in cassava stake before growing in Yasothon soil series

\begin{tabular}{lll}
\hline \multirow{2}{*}{ Cassava stake } & \multicolumn{2}{c}{ Cassava varieties } \\
\cline { 2 - 3 } & Kasetsart 50 & CMR 33-38-48 \\
\hline N content $(\%)$ & 0.05 & 0.04 \\
P content $(\mathrm{ppm})$ & 2.53 & 2.85 \\
K content $(\%)$ & 0.01 & 0.01 \\
Stake moisture content $(\%)^{* *}$ & $76.71 \mathrm{a}$ & $67.28 \mathrm{~b}$ \\
Stake height $(\mathrm{cm})^{*}$ & $144.75 \mathrm{a}$ & $127.50 \mathrm{~b}$ \\
\hline
\end{tabular}

Note. Different letters indicate a significant difference at $\mathrm{p} \leq 0.01 * *$ and $0.05^{*}$.

\subsection{Germination and Growth of Cassava at 4 Months After Planting}

After two cassava varieties were planted under various fertilizer managements at 1 month, the germination percentages of the two cassavas were not significantly different, even though Kasetsart 50 had higher stake moisture content than CMR 33-38-48. This is because 1 month after cassava planting was the beginning of the rainy season. The germination percentages of both cassava varieties were $98.57-99.55 \%$. Cassava is an economic plant that stores photosynthates in the roots part which is accumulate $70-80 \%$ carbohydrates by dry weight during growth stages. For the rest of carbohydrates obtained was stored in the leaves, stem and young leaves that are growing. Cassava grown in the tropics has the highest growth rate at the age of 3-5 months (Howeler and Cadavid, 1982). At 4 months after planting, plant height and leaf dry weight were significantly different lower in Kasetsart 50 with $6,250 \mathrm{~kg} \mathrm{ha}^{-1}$ of organic fertilizer also leaf area per plant was significantly different and lower in Kasetsart 50 with $312.50 \mathrm{~kg} \mathrm{ha}^{-1}$ of 15-15-15 (Table 3). While stem dry weight of CMR 33-38-48 with 312.50 $\mathrm{kg} \mathrm{ha}^{-1}$ of 15-7-18 tended to produce more than Kasetsart 50 with $6,250 \mathrm{~kg} \mathrm{ha}^{-1}$ of organic fertilizer and 312.50 $\mathrm{kg} \mathrm{ha}^{-1}$ of 15-15-15. However, Kasetsart 50 tended to build storage roots faster than CMR 33-38-48 and had more storage roots per plant. However, the storage roots size of CMR 33-38-48 was bigger than Kasetsart 50, especially under chemical fertilizer application. Therefore, this resulted in both fresh and dry weights higher than Kasetsart 50, except with $6,250 \mathrm{~kg} \mathrm{ha}^{-1}$ of organic fertiliser. This corresponds to the growth of the stems that allow the CMR 33-38-48 transport photosynthates to the storage root as much as the growth rate of shoots/roots also. Sukthamrong and Khamlert (2010) reported that chemical fertilizer should use at the ratio of 2:1:2, and the fertilizer recommended is $15-7-18$ or 15-15-15 for loamy sand at the rate of $468.75 \mathrm{~kg} \mathrm{ha}^{-1}$, for sandy loam and sticky loam at the rate of $312.50 \mathrm{~kg} \mathrm{ha}^{-1}$ and the rate of $156.25 \mathrm{~kg} \mathrm{ha}^{-1}$ for brown, red and black clay. Kasetsart 50 responded to organic fertilizer management with a higher number of storage roots as well as the fresh and dry weights of storage roots. Organic fertilizer has important nutrients such as zinc ( $\mathrm{Zn}$ ), which is an essential component of many enzymes, plant hormones and chlorophyll production as well as playing a role in protein synthesis to promote the utilisation of phosphorus and nitrogen in plants (Cassava and Product Research Center Suranaree University of Technology, 2008). Boron (B) plays an important role in fruiting and transferring sugar to the fruit, hormonal movement and the utilisation of nitrogen and cell division. Copper $(\mathrm{Cu})$ and iron $(\mathrm{Fe})$ help in the synthesis of chlorophyll, respiration and the use of protein and starch as well as stimulating the activity of enzymes. Therefore, cassava cultivation requires fertilizer to stimulate growth and production. The amounts of nutrients accumulate in different parts of cassava. Growth of cassava stems and leaves at the beginning, resulting in the accumulation of nitrogen, phosphorus and potassium, especially in the leaves followed by the stems, petioles and storage roots. Potassium and phosphorus play a role in the transport of nutrients to different parts and the development of storage root productivity. CMR 33-38-48 tended to accumulate macronutrients in different parts more than Kasetsart 50, especially nitrogen contents in the leaves under organic fertilizer management (Table 4). However, management with chemical and organic fertilizer will not only promote the growth of the crops but also increase plant nutrient absorption and maintain soil fertility (Bureau of Soil Resources Research and Research Department of Land Development Ministry of Agriculture and Cooperatives, 2003). 
Table 3. Effect of varieties and fertilizer application methods on cassava growth at 4 months after planting

\begin{tabular}{llllllllll}
\hline Treatments & Height $(\mathrm{cm})$ & $\begin{array}{l}\text { Leaf area } \\
\text { plant }^{-1}\left(\mathrm{~cm}^{2}\right)\end{array}$ & $\begin{array}{l}\text { Storage } \\
\text { root } \\
\text { no./plant }\end{array}$ & $\begin{array}{l}\text { Leaf dry } \\
\text { weight } \\
\text { plant }^{-1}(\mathrm{~g})\end{array}$ & $\begin{array}{l}\text { Stem dry } \\
\text { weight } \\
\text { plant }^{-1}(\mathrm{~g})\end{array}$ & $\begin{array}{l}\text { Total top } \\
\text { dry weight } \\
\text { plant }^{-1}(\mathrm{~g})\end{array}$ & $\begin{array}{l}\text { Storage root } \\
\text { dry weight } \\
\text { plant }^{-1}(\mathrm{~g})\end{array}$ & $\begin{array}{l}\text { Storage root } \\
\text { fresh weight } \\
\text { plant }^{-1}(\mathrm{~g})\end{array}$ & $\begin{array}{l}\text { Shoot root } \\
\text { Sh }^{-1}\end{array}$ \\
\hline TR1 & $74.42 \mathrm{ab}$ & $11,082 \mathrm{~b}$ & $10.17 \mathrm{ab}$ & $33.42 \mathrm{abc}$ & $69.45 \mathrm{~b}$ & $110.88 \mathrm{c}$ & $106.11 \mathrm{ab}$ & $300.83 \mathrm{~b}$ & $1.16 \mathrm{ab}$ \\
TR2 & $85.67 \mathrm{a}$ & $16,928 \mathrm{a}$ & $6.17 \mathrm{bc}$ & $36.73 \mathrm{ab}$ & $79.01 \mathrm{ab}$ & $138.98 \mathrm{a}$ & $133.35 \mathrm{ab}$ & $379.58 \mathrm{ab}$ & $1.13 \mathrm{~b}$ \\
TR3 & $74.74 \mathrm{ab}$ & $11,226 \mathrm{ab}$ & $10.58 \mathrm{a}$ & $33.42 \mathrm{abc}$ & $80.02 \mathrm{ab}$ & $131.27 \mathrm{abc}$ & $157.78 \mathrm{ab}$ & $424.17 \mathrm{ab}$ & $1.01 \mathrm{~b}$ \\
TR4 & $80.43 \mathrm{ab}$ & $15,446 \mathrm{ab}$ & $7.67 \mathrm{abc}$ & $37.81 \mathrm{a}$ & $84.40 \mathrm{a}$ & $142.75 \mathrm{a}$ & $192.95 \mathrm{a}$ & $600.41 \mathrm{a}$ & $0.94 \mathrm{~b}$ \\
TR5 & $67.94 \mathrm{~b}$ & $15,081 \mathrm{ab}$ & $9.34 \mathrm{ab}$ & $29.16 \mathrm{bc}$ & $69.25 \mathrm{~b}$ & $115.56 \mathrm{bc}$ & $146.97 \mathrm{ab}$ & $392.50 \mathrm{ab}$ & $0.86 \mathrm{~b}$ \\
TR6 & $78.46 \mathrm{ab}$ & $15,413 \mathrm{ab}$ & $4.42 \mathrm{c}$ & $33.97 \mathrm{abc}$ & $82.36 \mathrm{ab}$ & $135.97 \mathrm{ab}$ & $77.04 \mathrm{~b}$ & $259.58 \mathrm{~b}$ & $2.00 \mathrm{a}$ \\
\hline
\end{tabular}

Note. TR1 $=$ Kasetsart $50+312.50 \mathrm{~kg} \mathrm{ha}^{-1}$ of 15-15-15; TR2 $=$ CMR 33-38-48 + 312.50 kg ha ${ }^{-1}$ of 15-15-15; TR3 = Kasetsart $50+312.50 \mathrm{~kg} \mathrm{ha}^{-1}$ of 15-7-18; TR4 = CMR 33-38-48 $+312.50 \mathrm{~kg} \mathrm{ha}^{-1}$ of 15-7-18; TR5 = Kasetsart $50+6,250 \mathrm{~kg} \mathrm{ha}^{-1}$ of organic fertilizer; TR6 $=$ CMR 33-38-48 $+6,250 \mathrm{~kg} \mathrm{ha}^{-1}$ of organic fertilizer.

Different letters indicate a significant difference at $\mathrm{p} \leq 0.05^{*}$.

Table 4. Macronutrients content of cassava at 4 months after planting

\begin{tabular}{llllllllllllll}
\hline \multirow{2}{*}{ Treatment } & \multicolumn{3}{l}{ Storage root (\%) } & \multicolumn{3}{l}{ Stem (\%) } & \multicolumn{3}{c}{ Petioles (\%) } & \multicolumn{3}{l}{ Leaves (\%) } \\
\cline { 2 - 14 } & $\mathrm{N}$ & $\mathrm{P}^{*}$ & $\mathrm{~K}$ & $\mathrm{~N}^{*}$ & $\mathrm{P}$ & $\mathrm{K}^{*}$ & $\mathrm{~N}$ & $\mathrm{P}^{*}$ & $\mathrm{~K}^{*}$ & $\mathrm{~N}^{* *}$ & $\mathrm{P}^{*}$ & $\mathrm{~K}^{*}$ \\
\hline TR1 & 1.84 & $0.25 \mathrm{a}$ & 3.38 & $3.07 \mathrm{a}$ & 0.63 & $3.33 \mathrm{ab}$ & 3.22 & $0.91 \mathrm{a}$ & $2.54 \mathrm{ab}$ & $13.73 \mathrm{~d}$ & $0.63 \mathrm{~b}$ & $4.40 \mathrm{~b}$ \\
TR2 & 2.27 & $0.19 \mathrm{~b}$ & 3.13 & $2.74 \mathrm{ab}$ & 0.54 & $3.47 \mathrm{a}$ & 3.27 & $0.58 \mathrm{~b}$ & $2.56 \mathrm{ab}$ & $15.53 \mathrm{bc}$ & $0.77 \mathrm{a}$ & $4.69 \mathrm{~b}$ \\
TR3 & 1.68 & $0.23 \mathrm{ab}$ & 3.19 & $2.77 \mathrm{ab}$ & 0.59 & $2.80 \mathrm{~b}$ & 3.20 & $0.68 \mathrm{ab}$ & $2.23 \mathrm{~b}$ & $14.37 \mathrm{~cd}$ & $0.73 \mathrm{ab}$ & $5.37 \mathrm{ab}$ \\
TR4 & 1.65 & $0.20 \mathrm{~b}$ & 3.27 & $2.35 \mathrm{~b}$ & 0.51 & $3.23 \mathrm{ab}$ & 3.14 & $0.64 \mathrm{ab}$ & $2.69 \mathrm{ab}$ & $16.35 \mathrm{ab}$ & $0.76 \mathrm{a}$ & $4.82 \mathrm{~b}$ \\
TR5 & 1.48 & $0.21 \mathrm{ab}$ & 3.08 & $2.92 \mathrm{ab}$ & 0.68 & $2.81 \mathrm{~b}$ & 3.21 & $0.65 \mathrm{ab}$ & $2.54 \mathrm{ab}$ & $14.62 \mathrm{bcd}$ & $0.71 \mathrm{ab}$ & $5.01 \mathrm{ab}$ \\
TR6 & 1.76 & $0.22 \mathrm{ab}$ & 3.03 & $2.47 \mathrm{ab}$ & 0.66 & $3.39 \mathrm{ab}$ & 3.59 & $0.93 \mathrm{a}$ & $3.16 \mathrm{a}$ & $17.35 \mathrm{a}$ & $0.80 \mathrm{a}$ & $6.26 \mathrm{a}$ \\
\hline
\end{tabular}

Note. TR1 $=$ Kasetsart $50+312.50 \mathrm{~kg} \mathrm{ha}^{-1}$ of 15-15-15; TR2 $=$ CMR 33-38-48 + 312.50 kg ha ${ }^{-1}$ of 15-15-15; TR3 $=$ Kasetsart $50+312.50 \mathrm{~kg} \mathrm{ha}^{-1}$ of 15-7-18; TR4 = CMR 33-38-48+312.50 $\mathrm{kg} \mathrm{ha}^{-1}$ of 15-7-18; TR5 = Kasetsart $50+6,250 \mathrm{~kg} \mathrm{ha}^{-1}$ of organic fertilizer; TR6 $=$ CMR 33-38-48 $+6,250 \mathrm{~kg} \mathrm{ha}^{-1}$ of organic fertilizer.

Different letters indicate a significant difference at $\mathrm{p} \leq 0.01^{* *}$ and $\mathrm{p} \leq 0.05^{*}$.

\subsection{The Growth of Cassava After Planting for 8 Months}

The growth rate of the above-ground portions/roots decreased from the age of 4 months because most photosynthates are used to form storage roots and accumulate dry weight in different parts were not significantly different (Table 5) including storage root fresh weight. The leaf area per plant was measured by leaf area meter with Li-cor 3100 and the data decreased due to drought impact on cassava growth after 4 months, causing cassava leaves to fall and decreasing in the leaf size, especially CMR 33-38-48 with $312.50 \mathrm{~kg} \mathrm{ha}^{-1}$ of 15-15-15. Kasetsart 50 still had more tuber numbers per plant than CMR 33-38-48, and the tuber size was smaller. CMR 33-38-48 with $312.50 \mathrm{~kg} \mathrm{ha}^{-1}$ of 15-7-18 tended to produce higher storage root fresh and dry weights followed by organic fertilizer at the rate of $6,250 \mathrm{~kg} \mathrm{ha}^{-1}$ and $312.50 \mathrm{~kg} \mathrm{ha}^{-1}$ of $15-15-15$, respectively. Saengkla (2006) reported that cassava plantation under organic fertiliser will receive smaller amounts of nitrogen $(\mathrm{N})$, phosphorus (P) and potassium (K) than chemical fertilizer application at the rate of $312.50 \mathrm{~kg} \mathrm{ha}^{-1}$. The amounts of nutrients accumulated in different parts of cassava. After growing for 8 months, the cassava growth rate decreased with the decrease of macronutrients in various parts, especially the amount of nitrogen and potassium accumulation in the leaves followed by the petiole, storage root and stem. Potassium plays a role in the accumulation of flour in the storage root. The results showed that chemical fertilizer application in both cassava varieties accumulated higher potassium than the application of organic fertilizer (Table 6). 
Table 5. Effect of varieties and fertilizer application methods on cassava growth at 8 months after planting

\begin{tabular}{|c|c|c|c|c|c|c|c|c|c|}
\hline Treatments & Height $(\mathrm{cm})$ & $\begin{array}{l}\text { Leaf area } \\
\text { plant }^{-1}\left(\mathrm{~cm}^{2}\right)\end{array}$ & $\begin{array}{l}\text { Storage } \\
\text { root } \\
\text { no./plant }\end{array}$ & $\begin{array}{l}\text { Leaf dry } \\
\text { weight } \\
\text { plant }^{-1}(g)\end{array}$ & $\begin{array}{l}\text { Stem dry } \\
\text { weight } \\
\text { plant }^{-1}(\mathrm{~g})\end{array}$ & $\begin{array}{l}\text { Total top } \\
\text { dry weight } \\
\text { plant }^{-1}(\mathrm{~g})\end{array}$ & $\begin{array}{l}\text { Storage root } \\
\text { dry weight } \\
\text { plant }^{-1}(\mathrm{~g})\end{array}$ & $\begin{array}{l}\text { Storage root } \\
\text { fresh weight } \\
\text { plant }^{-1}(\mathrm{~g})\end{array}$ & Shoot $\operatorname{root}^{-1}$ \\
\hline TR1 & $75.36 \mathrm{abc}$ & $4,664.30 \mathrm{ab}$ & $10.50 \mathrm{ab}$ & 24.29 & 55.59 & 86.10 & 333.27 & $1,046.70$ & 0.29 \\
\hline TR2 & $84.88 \mathrm{ab}$ & $3,250.20 \mathrm{~b}$ & $6.34 \mathrm{bc}$ & 16.90 & 53.19 & 75.01 & 388.22 & $1,260.40$ & 0.19 \\
\hline TR3 & $75.14 b c$ & 4,296.40ab & $12.42 \mathrm{a}$ & 21.36 & 50.69 & 77.27 & 391.73 & $1,142.50$ & 0.20 \\
\hline TR4 & $82.15 \mathrm{abc}$ & $4,063.70 \mathrm{ab}$ & $6.75 \mathrm{bc}$ & 20.27 & 57.01 & 77.27 & 437.73 & $1,441.70$ & 0.20 \\
\hline TR5 & $68.75 \mathrm{c}$ & $4,449.10 \mathrm{ab}$ & $9.00 \mathrm{abc}$ & 21.99 & 45.40 & 73.14 & 354.38 & $1,125.80$ & 0.23 \\
\hline TR6 & $89.52 \mathrm{a}$ & $5,076.60 \mathrm{a}$ & $5.17 \mathrm{c}$ & 24.87 & 56.17 & 89.99 & 426.57 & $1,397.50$ & 0.23 \\
\hline
\end{tabular}

Note. TR1 $=$ Kasetsart $50+312.50 \mathrm{~kg} \mathrm{ha}^{-1}$ of 15-15-15; TR2 $=$ CMR 33-38-48 + 312.50 kg ha ${ }^{-1}$ of 15-15-15; TR3 $=$ Kasetsart $50+312.50 \mathrm{~kg} \mathrm{ha}^{-1}$ of 15-7-18; TR4 = CMR 33-38-48 $+312.50 \mathrm{~kg} \mathrm{ha}^{-1}$ of 15-7-18; TR5 = Kasetsart $50+6,250 \mathrm{~kg} \mathrm{ha}^{-1}$ of organic fertilizer; TR6 $=$ CMR 33-38-48 $+6,250 \mathrm{~kg} \mathrm{ha}^{-1}$ of organic fertilizer.

Different letters indicate a significant difference at $\mathrm{p} \leq 0.05^{*}$.

Table 6. Macronutrients content of cassava at 8 months after planting

\begin{tabular}{|c|c|c|c|c|c|c|c|c|c|c|c|c|}
\hline \multirow{2}{*}{ Treatments } & \multicolumn{3}{|c|}{ Storage root $(\%)$} & \multicolumn{3}{|c|}{ Stem $(\%)$} & \multicolumn{3}{|c|}{ Petioles (\%) } & \multicolumn{3}{|c|}{ Leaves (\%) } \\
\hline & $\mathrm{N}$ & $\mathrm{P}^{*}$ & $\mathrm{~K}^{*}$ & $\mathrm{~N}^{*}$ & $\mathrm{P} *$ & $\mathrm{~K}$ & $\mathrm{~N}$ & $\mathrm{P} * *$ & $\mathrm{~K}^{* *}$ & $\mathrm{~N}$ & $\mathrm{P} * *$ & $\mathrm{~K}$ \\
\hline TR1 & 0.40 & $0.04 \mathrm{a}$ & $0.65 \mathrm{ab}$ & $0.85 \mathrm{ab}$ & $0.13 \mathrm{ab}$ & 0.45 & 1.01 & $0.08 \mathrm{a}$ & $0.71 \mathrm{a}$ & 3.05 & $0.15 b c$ & 1.01 \\
\hline TR2 & 0.41 & $0.03 b$ & $0.70 \mathrm{ab}$ & $0.83 \mathrm{ab}$ & $0.10 \mathrm{bc}$ & 0.46 & 1.05 & $0.06 \mathrm{bc}$ & $0.50 \mathrm{c}$ & 3.40 & $0.17 \mathrm{ab}$ & 1.00 \\
\hline TR3 & 0.38 & $0.03 b$ & $0.66 \mathrm{ab}$ & $0.86 \mathrm{a}$ & $0.12 \mathrm{ab}$ & 0.43 & 0.87 & $0.05 \mathrm{c}$ & $0.61 b$ & 3.07 & $0.16 \mathrm{bc}$ & 0.99 \\
\hline TR4 & 0.36 & $0.03 b$ & $0.74 \mathrm{a}$ & $0.76 \mathrm{bc}$ & $0.07 \mathrm{c}$ & 0.45 & 0.91 & $0.07 \mathrm{~b}$ & $0.66 \mathrm{ab}$ & 3.28 & $0.19 \mathrm{a}$ & 0.99 \\
\hline TR5 & 0.37 & $0.03 b$ & $0.60 \mathrm{~b}$ & $0.82 \mathrm{abc}$ & $0.15 \mathrm{a}$ & 0.50 & 0.98 & $0.06 \mathrm{bc}$ & $0.67 \mathrm{ab}$ & 3.36 & $0.15 \mathrm{c}$ & 1.16 \\
\hline TR6 & 0.53 & $0.02 b$ & $0.60 \mathrm{~b}$ & $0.73 \mathrm{c}$ & $0.10 \mathrm{bc}$ & 0.47 & 1.08 & $0.07 \mathrm{~b}$ & $0.63 \mathrm{ab}$ & 3.24 & $0.18 \mathrm{a}$ & 1.04 \\
\hline
\end{tabular}

Note. TR1 $=$ Kasetsart $50+312.50 \mathrm{~kg} \mathrm{ha}^{-1}$ of 15-15-15; TR2 = CMR 33-38-48+312.50 kg ha ${ }^{-1}$ of 15-15-15; TR3 = Kasetsart $50+312.50 \mathrm{~kg} \mathrm{ha}^{-1}$ of 15-7-18; TR4 = CMR 33-38-48 $+312.50 \mathrm{~kg} \mathrm{ha}^{-1}$ of 15-7-18; TR5 = Kasetsart $50+6,250 \mathrm{~kg} \mathrm{ha}^{-1}$ of organic fertilizer; TR6 $=$ CMR 33-38-48 $+6,250 \mathrm{~kg} \mathrm{ha}^{-1}$ of organic fertilizer.

Different letters indicate a significant difference at $\mathrm{p} \leq 0.01^{* *}$ and $\mathrm{p} \leq 0.05^{*}$.

\subsection{Cassava Yield at Harvest Stage}

When cassava passed the dry season and enters to the beginning of the rainy season, cassava vegetative growth will increase again but the rate of growth is slower than at the beginning of growth. According to the photosynthates are used to increase the size of storage roots. However, the ability to create and accumulate starch in cassava roots is different. Due to cassava varieties, aging of harvesting, soil fertility and crop management. Therefore affecting the quantity and quality of cassava production especially, total starch percentage. Cassava varieties with the highest starch content were Rayong 90, Kasetsart 50, Rayong 5 and Rayong 72 respectively (Department of Agriculture, 2014). The results showed that Kasetsart 50 has the number of storage roots per plant higher than CMR 33-38-48 (Table 7), but CMR 33-38-48 gave more storage root fresh weight than Kasetsart 50 by the water content is greater than the amount of starch accumulated compared to cassava variety Kasetsart 50. Cassava storage root size was larger at the age of 12 months (Table 8). CMR 33-38-48 with organic fertilizer at the rate of $6,250 \mathrm{~kg} \mathrm{ha}^{-1}$ tended to produce higher storage root fresh weights followed by $312.50 \mathrm{~kg}$ $\mathrm{ha}^{-1}$ of 15-7-18, the same as Kasetsart 50. CMR 33-38-48 with $312.50 \mathrm{~kg} \mathrm{ha}^{-1}$ of $15-7-18,312.50 \mathrm{~kg} \mathrm{ha}^{-1}$ of 15-15-15 and 6,250 $\mathrm{kg} \mathrm{ha}^{-1}$ of organic fertiliser had a significantly different lower percentage of total starch respectively and amylose content in the storage roots (Table 8). 
Table 7. Effect of varieties and fertiliser application methods on cassava growth at 12 months after planting

\begin{tabular}{|c|c|c|c|c|c|c|c|c|c|}
\hline Treatments & Height $(\mathrm{cm})$ & $\begin{array}{l}\text { Leaf area } \\
\text { plant }^{-1}\left(\mathrm{~cm}^{2}\right)\end{array}$ & $\begin{array}{l}\text { Storage } \\
\text { root } \\
\text { no./plant }\end{array}$ & $\begin{array}{l}\text { Leaf dry } \\
\text { weight } \\
\text { plant }^{-1}(\mathrm{~g})\end{array}$ & $\begin{array}{l}\text { Stem dry } \\
\text { weight } \\
\text { plant }^{-1}(\mathrm{~g})\end{array}$ & $\begin{array}{l}\text { Total top } \\
\text { dry weight } \\
\text { plant }^{-1}(\mathrm{~g})\end{array}$ & $\begin{array}{l}\text { Storage root } \\
\text { dry weight } \\
\text { plant }^{-1}(\mathrm{~g})\end{array}$ & $\begin{array}{l}\text { Storage root } \\
\text { fresh weight } \\
\text { plant }^{-1}(\mathrm{~g})\end{array}$ & Shoot $\operatorname{root}^{-1}$ \\
\hline TR1 & $117.28 \mathrm{bc}$ & $249.18 \mathrm{a}$ & $8.25 b$ & $59.65 \mathrm{ab}$ & $113.89 \mathrm{bc}$ & $198.44 b c$ & $1,172.90 \mathrm{bc}$ & $4,046.70 \mathrm{~b}$ & $0.19 \mathrm{a}$ \\
\hline TR2 & $135.74 \mathrm{ab}$ & $170.39 \mathrm{c}$ & $7.00 \mathrm{~b}$ & $67.38 \mathrm{ab}$ & $145.62 \mathrm{ab}$ & $240.04 \mathrm{ab}$ & $1,027.40 \mathrm{c}$ & $4,166.70 \mathrm{~b}$ & $0.24 \mathrm{a}$ \\
\hline TR3 & $122.86 \mathrm{abc}$ & $218.27 b$ & $11.00 \mathrm{a}$ & $78.64 a$ & $124.24 b c$ & $235.94 \mathrm{ab}$ & $1,452.80 \mathrm{ab}$ & $5,265.00 \mathrm{ab}$ & $0.17 \mathrm{ab}$ \\
\hline TR4 & $135.79 \mathrm{ab}$ & $175.13 \mathrm{c}$ & $6.50 \mathrm{~b}$ & $59.78 \mathrm{ab}$ & $150.60 \mathrm{ab}$ & $237.75 \mathrm{ab}$ & $1,320.00 \mathrm{abc}$ & $5,670.00 \mathrm{a}$ & $0.18 \mathrm{a}$ \\
\hline TR5 & $103.55 \mathrm{c}$ & $209.83 b$ & $8.08 \mathrm{~b}$ & $50.60 \mathrm{~b}$ & $92.38 \mathrm{c}$ & $164.99 \mathrm{c}$ & $1,569.00 \mathrm{a}$ & $5,406.70 \mathrm{ab}$ & $0.11 \mathrm{~b}$ \\
\hline TR6 & $142.53 a$ & $192.78 b c$ & $5.75 b$ & $80.57 \mathrm{a}$ & $179.51 \mathrm{a}$ & $296.25 \mathrm{a}$ & $1,471.30 \mathrm{ab}$ & $6,387.50 \mathrm{a}$ & $0.20 \mathrm{a}$ \\
\hline
\end{tabular}

Note. TR1 $=$ Kasetsart $50+312.50 \mathrm{~kg} \mathrm{ha}^{-1}$ of 15-15-15; TR2 = CMR 33-38-48 + 312.50 kg ha ${ }^{-1}$ of 15-15-15; TR3 $=$ Kasetsart $50+312.50 \mathrm{~kg} \mathrm{ha}^{-1}$ of 15-7-18; TR4 = CMR 33-38-48 $+312.50 \mathrm{~kg} \mathrm{ha}^{-1}$ of 15-7-18; TR5 = Kasetsart $50+6,250 \mathrm{~kg} \mathrm{ha}^{-1}$ of organic fertilizer; TR6 $=$ CMR 33-38-48 $+6,250 \mathrm{~kg} \mathrm{ha}^{-1}$ of organic fertilizer.

Different letters indicate a significant difference at $\mathrm{p} \leq 0.01^{* *}$ and $\mathrm{p} \leq 0.05^{*}$.

Table 8. Total starch, amylose content and storage root fresh weight of cassava at 12 months after planting

\begin{tabular}{llll}
\hline Treatments & Total starch $(\%)^{*}$ & Amylose $(\%)^{*}$ & Storage root fresh weight kg ha ${ }^{-1}$ \\
\hline TR1 & $18.38 \mathrm{a}$ & $31.53 \mathrm{ab}$ & $50,581.25 \mathrm{~b}$ \\
TR2 & $14.23 \mathrm{bc}$ & $28.16 \mathrm{~b}$ & $52,083.75 \mathrm{~b}$ \\
TR3 & $17.90 \mathrm{a}$ & $33.79 \mathrm{a}$ & $65,812.50 \mathrm{ab}$ \\
TR4 & $11.98 \mathrm{c}$ & $32.30 \mathrm{ab}$ & $70,875.00 \mathrm{a}$ \\
TR5 & $20.18 \mathrm{a}$ & $32.30 \mathrm{ab}$ & $67,583.75 \mathrm{ab}$ \\
TR6 & $14.53 \mathrm{~b}$ & $31.45 \mathrm{ab}$ & $79,843.75 \mathrm{a}$ \\
\hline
\end{tabular}

Note. TR1 $=$ Kasetsart $50+312.50 \mathrm{~kg} \mathrm{ha}^{-1}$ of 15-15-15; TR2 = CMR 33-38-48+312.50 $\mathrm{kg} \mathrm{ha}^{-1}$ of $15-15-15$; $\mathrm{TR} 3=$ Kasetsart $50+312.50 \mathrm{~kg} \mathrm{ha}^{-1}$ of 15-7-18; TR4 = CMR 33-38-48 + 312.50 $\mathrm{kg} \mathrm{ha}^{-1}$ of 15-7-18; TR5 = Kasetsart 50+6,250 kg ha ${ }^{-1}$ of organic fertilizer; TR6 $=$ CMR 33-38-48 $+6,250 \mathrm{~kg} \mathrm{ha}^{-1}$ of organic fertilizer.

Different letters indicate a significant difference at $\mathrm{p} \leq 0.05^{*}$.

\section{Conclusions}

In the production of fresh storage roots, total starch and amylose percentage, Kasetsart 50 and CMR 33-38-48 responded to chemical and organic fertilizer management, especially $312.50 \mathrm{~kg} \mathrm{ha}^{-1}$ of $15-7-18$ and $6,250 \mathrm{~kg} \mathrm{ha}^{-1}$ of organic fertilizer. In addition, CMR 33-38-48 tends to grow well and provide more storage root fresh weight per area. However, other factors affect the amount of starch accumulation in the cassava storage root, such as the harvest season. For further experiments, the quantity of organic and chemical fertilizers should be increased.

\section{Acknowledgements}

This research was supported by a General Research Grant 2018 to Khon Kaen University, Mahasarakham Research and Development Agriculture Centre, Mahasarakham province, Agronomy section and the North East Agriculture Research and Development Centre at the Faculty of Agriculture Khon Kaen University (Thailand).

\section{References}

Anusontpornperm, S., Nortcliff, S., \& Kheoruenromne, I. (2005). Hardpan formation of some coarse-textured upland soils in Thailand. Paper Presented at Management of Tropical Sandy Soils from Sustainable Agriculture, November 27-December 2005, Khon Kaen, Thailand.

Boonma, S., Wichitkij, V., \& Sarobol, E. (n.d.). Influence of duration and method of stake preservation on germination growth and yield of cassava. Retrieved August 2, 2013, from http://kucon.lib.ku.ac.th/Fulltext/ KC4501017.pdf

Bureau of Soil Resources Research and Research Department of Land Development Ministry of Agriculture and Cooperatives. (2003). Essential nutrients on plant growth. Retrieved September 18, 2016, from http://oss101.ldd.go.th/web_soils_for_youth/s_prop_nutri02.htm 
Cassava and Product Research Center Suranaree University of Technology. (2008). Problems of low cassava production due to lack of zinc. Retrieved September 17, 2016, from http://web.sut.ac.th/cassava/index. php?name $=14$ cas_plant\&file $=$ readknowledge $\&$ id $=60$

Chutangka, S. (2008). Academic documents Cassava Production Technology. Rayong Crops Research Center Department of Agriculture.

Department of Agriculture. (2014). Comparison of Cassava Varieties in Farmers Farms. Retrieved June 14, 2018, from http://www.doa.go.th/research/archive/index.php?thread-2156.html

Department of Land Development. (2004). Knowledge of Thai soil series. Retrieved June 14, 2018, from http://www.ldd.go.th/dinthai

Howeler, R. H., Cadavid, L. F., \& Burckhardt, E. (1982). Response of cassava to VA mycorrhizal Inoculation and phosphorus application in greenhouse and field experiments. Plant and Soil, 69, 327-339. https://doi.org/10.1007/BF02372454

Ministry of Commerce. (2016). Thai Hom Rice Rice Product Standards (Book 133, Special Chapter 243).

Office of Agricultural Economics. (2004). Tapioca. Retrieved August 2, 2013, from http://www.oae.go. th/view/1/\%E0\%B8\%A1\%E0\%B8\%B1\%E0\%B8\%99\%E0\%B8\%AA\%E0\%B8\%B3\%E0\%B8\%9B\%E0\%B 8\%B0\%Е0\%B8\%AB\%Е0\%B8\%A5\%Е0\%B8\%B1\%Е0\%B8\%87/TH-TH

Office of Agricultural Economics. (2015). Agricultural Economics Information by Product Year 2014. Retrieved August 16, 2015, from http://www.oae.go.th/main.php?filename=journal_all

Phankamonsil, N., \& Wiriyaphanit, K. (2017). Effects of fertiliser management on soil properties growth and yield of cassava in Yasothon soil series. Kaen Kaset 4, 5(3), 505-514.

Saengkla, C., Kantho, U., Chutphonphon, S., Lertabhiran, N., Thawaphan, C., \& Wichukit, V. (2006). The effect of various kinds of liquid organic fertiliser foliar growth, yield and starch content of cassava varieties Huai Bong 60 (pp. 144-152). Kasetsart University Annual Conference 44: Crop Year 2006, 30 January-2 February 2006, Bangkok.

Sukthamrong, A., \& Khamlert, R. (2010). Techniques for increasing cassava production. Retrieved September 16,2016 , from $\mathrm{http} / / /$ web.sut.ac.th/cassava/?name $=10 \mathrm{cas} \_$technology $\&$ file $=$ readknowledge $\& \mathrm{id}=22$

Sungthongwises, K., Promkhambut, A., Laoken, A., \& Polthanee, A. (2016). Effects of methods and duration storage on cassava stake characteristics. Asian Journal of Plant Sciences, 15, 86-91. https://doi.org/ 10.3923/ajps.2016.86.91

Thongsri, S., Limsilachiraporn, A., Khao, P., \& Worn, W. (2007). Cassava (p. 12). Annual Crop Meeting 2007, 28-30 August 2007. Department of Agriculture, Ministry of Agriculture and Cooperatives, Mae Hong Son.

Wanasai, N., Thongsai, K., Pannara, N., \& Buaket, S. (2014). Testing of cassava production technology using rainwater in Phitsanulok province. Full report of the experiment at the end of the fiscal year 2014.

Wargiono, J., Guritno, B., Sugito, Y., \& Widodo, Y. (1995). Recent progress in cassava agronomyresearch in Indonesia. In R. H. Howeler (Ed.), Cassava Breeding, Agronomy Research andTechnology Transfer in Asia (pp. 147-174). Proc. $4^{\text {th }}$ Regional Workshop held in Trivandrum, Nov. 2-6, 1993, Kerala, India.

\section{Copyrights}

Copyright for this article is retained by the author(s), with first publication rights granted to the journal.

This is an open-access article distributed under the terms and conditions of the Creative Commons Attribution license (http://creativecommons.org/licenses/by/4.0/). 